\title{
International Congress of Comparative Law
}

The International Academy of Comparative Law held its third Congress in London from 3 I July to 5 August I950. Members of the Congress, representing some 48 nations, were welcomed at the opening meeting by the Lord Chancellor of England and Mr. Justice Vaisey, and it was announced that Dr. Roscoe Pound, of Harvard University, had been elected as the new president of the Academy.

The programme of the Congress, as on previous occasions, included a section devoted to Ethnologie Juridique. The Committee dealing with this subject, which was presided over by Professor $\mathrm{H}$. Trimborn and Mr. Arthur Phillips, began by considering the scope and methods of Ethnological Jurisprudence (as the subject has generally been designated in England), and then turned its attention to a number of specific questions. Among the rapporteurs whose contributions were closely concerned with the field of African studies were Professor Max Gluckman, who discussed the relation between law and custom with particular reference to Bantu land tenure; Dr. J. G. Peristiany, who dealt with the question of La vengeance privée et l'intervention de ''autorite publique on the basis of his study of the Pokot (Suk) tribe of Kenya; and Mr. Arthur Phillips, who read a paper on Les cérémonies du mariage chez les indigènes.

\section{African Students in the United States}

A sURveY on the welfare of African students in the United States was carried out in 1948 under the auspices of the Phelps-Stokes fund with the aid of a grant from the Carnegie Corporation. The survey was undertaken by Dr. Ruth Sloan of the United States Department of State and Mr. Ivor Cummings of the British Colonial Office Welfare Department, who are the joint authors of a report published in $1949 .{ }^{\mathrm{I}}$ The sections of the report deal with the problems and needs of the student in Africa, in the United States, and on his return to Africa. It makes proposals relating to the selection of African students and the qualifications required for those desiring to study in the United States, and discusses existing educational facilities in Africa and the various forms of financial aid which are available from African and American sources. On the basis of interviews with 301 African students an evaluation both of the students and of the colleges at which they were studying is attempted, and a comparison is made of the educational standards in Africa with those in American schools. Analyses of replies to student questionnaires and of institutions in U.S.A. where African students are registered, are given in a series of tables. The survey was primarily a factfinding survey, so that the report is concerned mainly with a description and analysis of various aspects of the existing situation and confines its recommendations to practical suggestions relating to financial and welfare problems, such as the need for planned vacations, for adequate information about expenses, for regional conferences and the circulation of information about students, for advice about clothing, lodging, travel, \&c.

\section{A Venereal Diseases Survey in Southern Rhodesia}

DuRING the months of April to October I949, a Venereal Diseases Survey was undertaken in Southern Rhodesia with the object of ascertaining whether more rapid and more efficient methods of treatment could be instituted. The survey was carried out by Dr. R. R. Willcox of St. Mary's Hospital, London, assisted by a technician, Mr. Boulter, late of the Wellcome Institute, and Mrs. Boulter. Dr. Willcox and Mr. Boulter had both had previous experience in Africa. The unit was equipped with a car and a mobile pathological laboratory and in

I A Survey of African Students studying in the United States. Phelps-Stokes Fund, New York, 1949, pp. 78. 